\title{
Land cover dynamics influence distribution of breeding birds in the Great Plains, USA
}

\author{
R Scholtz ${ }^{\mathrm{a}, *, 1}$, JA Polo ${ }^{\mathrm{a}, 1}$, SD Fuhlendorf ${ }^{\mathrm{a}, 1}$, GD Duckworth ${ }^{\mathrm{b}}$ \\ a Department of Natural Resource Ecology and Management, Oklahoma State University, Stillwater, OK 74078, USA \\ ${ }^{\mathrm{b}}$ Centre for Statistics in Ecology, Environment and Conservation, Department of Statistics, University of Cape Town, Private Bag X3, Rondebosch 7701, South Africa
}

\section{A R T I C L E I N F O}

\section{Article history:}

Received 22 August 2016

Received in revised form 8 February 2017

Accepted 17 February 2017

Available online $\mathrm{xxxx}$

\section{Keywords:}

Communities

Grasslands

Landuse

Woodland encroachment

\begin{abstract}
A B S T R A C T
Grasslands are one of the most endangered ecosystems globally. Large tracts of grassland in the Great Plains, USA have been converted to cropland since the early 1900s, and woodlands are rapidly encroaching into many grasslands of the region due to changes in land management practices. Changes in the arrangement and proportion of different land cover types can affect biodiversity. We used bird survey data to identify the effect of land cover change on breeding bird ranges within the Great Plains over a 10-year period. Each species was categorized into one of the following habitat guilds: grassland, shrubland, woodland, wetland and generalist. We calculated the proportion of each land cover (including cropland, grassland, woodland, developed, barren, water bodies and wetlands) within a $1.6 \mathrm{~km}$ radius of each bird survey starting point. Within an occupancy modeling framework, we estimated colonization and extinction rates for each species and averaged them to the guild level. We also quantified changes in land cover from grassland to other cover types. Results show that grasslands were mostly converted to cropland and woodland, which were accompanied by positive extinction rates for certain grassland species. Extinction rates at the guild level were unrelated to increases in any land cover type, and observed land cover changes largely favored the shrubland guild. Overall, habitat-guild responses show little influence of woodland or cropland expansion at regional scales, although certain species ranges are predicted to decrease with increases in woodland. Future research should consider a finer scaled approach focusing on species-level responses when short-term land cover changes are considered.
\end{abstract}

@ 2017 Elsevier Ltd. All rights reserved.

\section{Introduction}

Grasslands provide key services, especially in terms of food production, and key habitats for a range of biodiversity (Davis et al., 2016; Fuhlendorf et al., 2006; Howland et al., 2016) yet are currently one of the most threatened ecosystems globally (Fargione et al., 2009; Samson and Knopf, 1994; Vickery et al., 1995). Since the late 18th century, major land cover changes, such as grassland conversion to cropland and, elsewhere, woody plant encroachment, have occurred across large portions of the Great Plains in North America. These changes have contributed to habitat reduction for many species and subsequent biodiversity loss (McLeman et al., 2014; Samson et al., 2004; WWF, 2016).

Despite widespread and ongoing grassland loss (Clark et al., 2002; Raz-Yaseef et al., 2015; WWF, 2016), the Great Plains region still maintains some of the largest areas of natural grasslands, about 37\%, in North

\footnotetext{
* Corresponding author.

E-mail address: r.scholtz@okstate.edu (R. Scholtz).

1 Postal Address: 008D Ag Hall, Department of Natural Resource Ecology and Management. Oklahoma State University, Stillwater, OK 74078, USA.
}

America (Han et al., 2012; Homer et al., 2015). Natural processes such as fire, which gives rise to heterogeneity in the arrangement and structure of vegetation, are essential to maximizing biodiversity and maintaining integrity of grassland ecosystems (Davis et al., 2016; Fuhlendorf et al., 2006; Vickery et al., 1995). Achieving a balance between meeting requirements for human survival, e.g. increases in crop-production to meet food and export demands, and maintaining natural grasslands and their associated ecosystem services are generally governed by two main approaches: land sparing vs. land sharing (Fischer et al., 2014; Phalan et al., 2011). Both approaches have limitations and benefits, yet it is becoming increasingly challenging to generalize its implementation (Fischer et al., 2011).

Woodland encroachment is another major driver of land cover change within the Great Plains region that arises from anthropogenic alteration of fire regimes (Berg et al., 2015; Engle et al., 2008; Heisler et al., 2003; Twidwell et al., 2013). Woodland encroachment profoundly effects ecological processes ranging from hydrologic cycles (Zou et al., 2015) to fire dynamics (Fuhlendorf et al., 2006; Twidwell et al., 2013; Weir and Scasta, 2014). However, in contrast to cropland expansion, woodland encroachment in grasslands encompasses a more complex association with fire regimes. Specifically, changes in fuel type (e.g. 
increases in coarse, woody biomass) influences fire severity and in turn fire regimes may be further influenced within this feedback loop (Keeley, 2009). As a consequence, ecological thresholds that change former grasslands into woodlands may be overcome by increasing fire activity (Briske et al., 2005; Fuhlendorf et al., 1996; Ratajczak et al., 2016).

Grassland birds throughout North America have been declining in recent decades (Sauer et al., 2014) and the primary cause of these declines is loss of habitat (Knopf and Samson, 1994; Samson and Knopf, 1994). Several arguments have been proposed for the mechanisms for grassland habitat loss such as fragmentation (Hobbs et al., 2008) and rangeland mismanagement (Briske et al., 2003) enabling debate for alternative management approaches (Bestelmeyer and Briske, 2012). Nevertheless, various drivers, such as changes in the fire regime and grazing, influence plant communities (Fuhlendorf and Engle, 2001). This leads to a reduction in diversity in grassland birds (Chapman et al., 2004a). Similarly, a reduction in grassland bird diversity has been associated with woodland expansion (Chapman et al., 2004b; Coppedge et al., 2001).

For this study, we used data from the North American Breeding Bird survey (BBS, Sauer et al., 2014) as an indicator for biodiversity within a highly utilized landscape. Birds are useful indicators of ecosystem health since they are mobile and respond quickly to land cover changes (Fuller, 2000; Gregory et al., 2003; Gregory et al., 2009) especially in grasslands (Coppedge et al., 2001). The influence of land-use (Duflot et al., 2015) configuration on breeding bird communities at regional scales has received substantial research in recent years (Bled et al., 2013; Duflot et al., 2015; Flather and Sauer, 1996; Gutzwiller et al., 2015). Since the Great Plains is a rapidly changing landscape with a substantial amount of grassland lost to croplands (WWF, 2016) and woodland encroachment, assessing changes in bird communities offers an important starting point for understanding regional biodiversity responses to land cover change. To this end, our study has two objectives:

(i) Quantify grassland loss and land cover conversion dynamics between 2006 and 2015

(ii) Quantify the effect of land cover change on breeding birds range dynamics (colonization and extinction) between 2006 and 2015 using the North America Bird Breeding Survey data (BBS, Sauer et al., 2014)

\section{Materials and methods}

\subsection{Study area}

The study area consisted of the states Oklahoma, Kansas, Nebraska, South Dakota and North Dakota within the central United States of America (Fig. 1) based on land cover data availability. Based on plant phenology, the vegetation growing season in this study area is generally from May through October and the dormant season from November through April. Natural vegetation cover in the region is comprised mainly of grasslands with interspersed stands of woody vegetation. Shortgrass prairie is more common in the west and tallgrass prairie in the east (Lauenroth et al., 1999). The climate ranges substantially throughout the region with extremely cold winters (mostly in the north) and hot and humid summers (mostly in the south). The southeastern part of the region received the most rainfall (mean annual precipitation (MAP) 1600 mm) with drier areas to the west and north (MAP $\sim 200 \mathrm{~mm}$ ). Mean annual temperature ranges from $\sim 3{ }^{\circ} \mathrm{C}$ in the north to $\sim 24^{\circ} \mathrm{C}$ in the south (PRISM Climate Group, 2004).

\subsection{Data acquisition and preparation}

\subsubsection{Land cover information}

Land cover data were sourced from cropscape.org (Han et al., 2012) for a 10 year study period (2006-2015) to estimate land cover dynamics. This period was selected because complete land cover data for our entire study area was only available from 2006 onwards. CropScape is an online tool that hosts Cropland Data Layer (CDL). The CDL is a georeferenced raster with a crop-specific land cover data layer created annually for the continental United States using the Advanced Wide Field Sensor (AWiFS) and Landsat TM 5 and ETM +7 with extensive agricultural ground truth employed (USDA National Agricultural Statistics Service Cropland Data Layer, 2016). According to Reitsma et al. (2016) who used South Dakota as a representative area for testing the accuracy of CropScape products, the overall accuracy for remotely sensed data relative to ground-truthed data was $84 \%$. Furthermore, cropland producer accuracy (\% of ground collected sites that were correctly identified) ranged from $89 \%$ in the east to $43 \%$ in the west. Grassland producer accuracy ranged from $95 \%$ in the northwest to $39 \%$ in the southeast in both 2006 and 2012 (see Liu et al., 2004 for more information).

All land cover pixels taken from CropScape were aggregated into one of the following broader categories; barren land, tree crops (e.g. apples), non-tree crops (e.g. wheat), grassland, evergreen and deciduous woodland which included shrubs (later lumped as "woodland"), developed, permanent water and wetlands. Aggregation was conducted for each year and scaled up to $3 \mathrm{~km}^{2}$ resolution. Land cover categories in the original data were determined by the Natural Resources Conservation Service. We simplified the categories prior to our analysis of the data. Thereafter, each pixel was classified by majority land cover type per year. We chose this method and scale as we were interested in broad patterns of land cover and we acknowledge that we may lose a substantial amount of information at this scale.

To obtain landscape-level land cover information at each bird survey starting point, we calculated the total proportion of each land cover type per year within a $1.6 \mathrm{~km}$ (1-mile), $5 \mathrm{~km}, 10 \mathrm{~km}$ and $50 \mathrm{~km}$ radius at each coordinate associated with the BBS starting point and compared land cover proportions at each scale. We acknowledge that this approach may not account for the entire $40 \mathrm{~km}$ route. However, a) GPS co-ordinates for every stop are not required (e.g. might not be recorded by each observer) and $\mathrm{b}$ ) given that the area covered by each route is not equal (e.g. all routes are not straight lines), we chose this approach to avoid any land cover sampling bias (Gutzwiller et al., 2015). Initial results suggest no major differences in the total proportion of grassland, cropland and woodland land cover types per year at either scale, and we opted to include the $1.6 \mathrm{~km}$ (1-mile) land cover data for our yearly covariate information (Appendix A Figs. A4-A6). This radius was chosen, as most sections bordered by a road in North America are 1-mile blocks and bird sightings are not recorded beyond $400 \mathrm{~m}$ from the road according to BBS protocol.

\subsubsection{Bird detection/non-detection data}

Bird data were sourced from the North American Bird Breeding Survey (BBS) database for 2006-2015 (Pardieck et al., 2014; Sauer et al., 2014). The BBS is based on annual counts of birds along pre-defined routes conducted by volunteers (Sauer et al., 2014). Each $40 \mathrm{~km}$ route consisted of 50 stops located every $0.8 \mathrm{~km}$ where all birds data seen and heard within a 3 min period are recorded (Sauer et al., 2014). A total of 180 routes were surveyed in our study area during the study period. We used all stop data from each route to designate whether or not each species was detected in each year (i.e., a detection/non-detection approach that we analyzed under an occupancy modeling framework, as described in detail below). Across the entire study area and study period, 314 total species were observed. However, we only included species for analysis if they were observed at least once at $\geq 40 \%$ of the points. We chose this threshold because we sought to only include relatively common breeding species and to exclude migrating and overwintering birds and other individuals and species that occasionally appear on surveys but are under-sampled using road-based point count surveys (e.g., waterfowl, raptors) (O'Connor et al., 2000). This reduced our sample size of species to 83. Each species was placed into one of five habitat guilds based on categories in Ehrlich et al. (1988) and The Cornell Lab of Ornithology (2016), 


\section{Ecoregions}

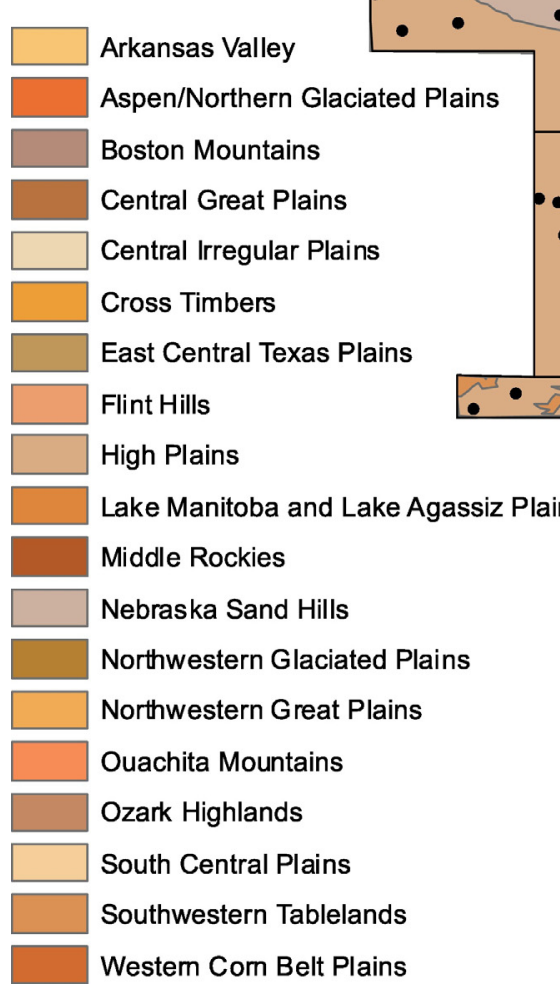
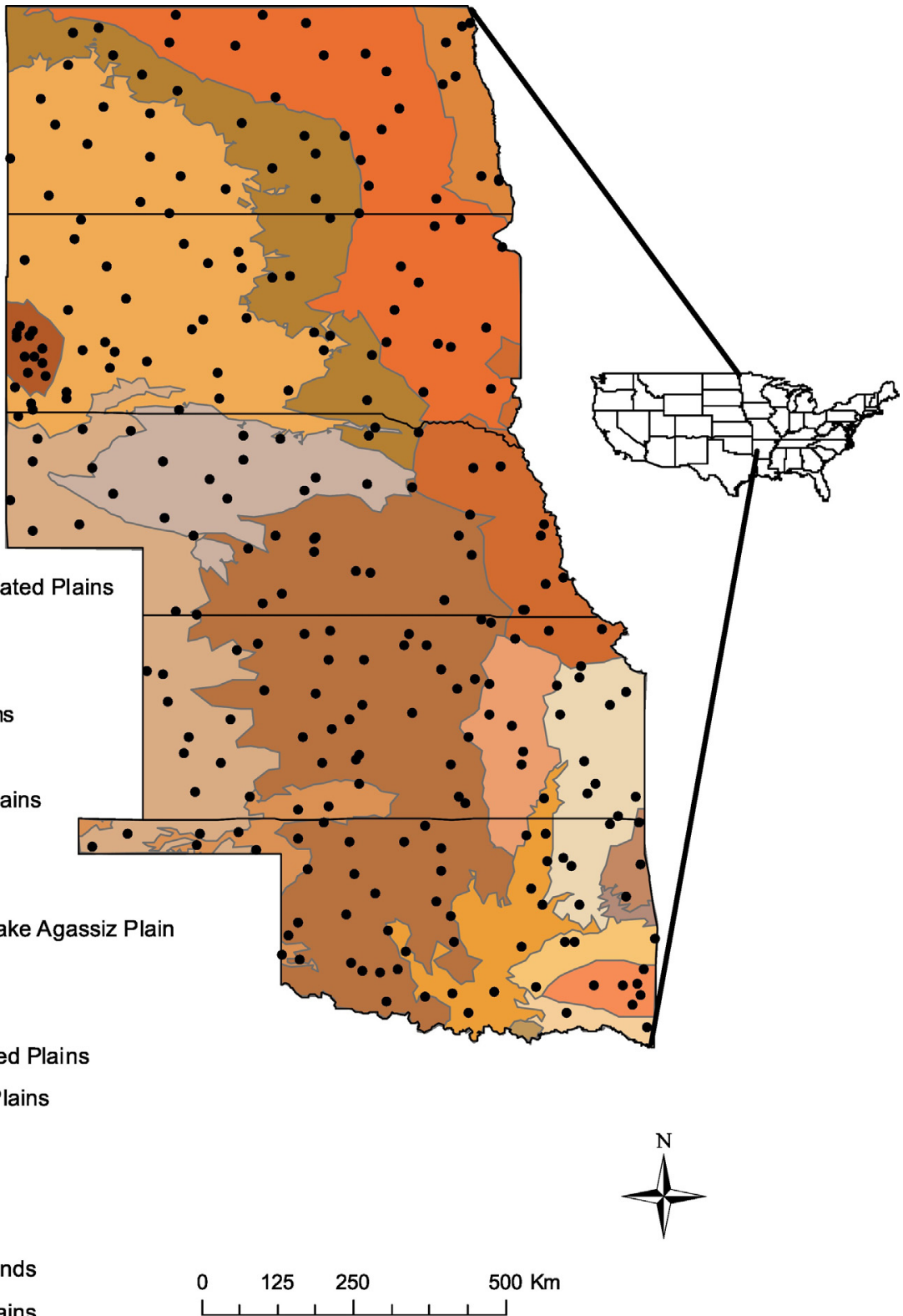

Fig. 1. Study area in the central-northern Great Plains, USA overlaid with ecoregions (Level 3) (U.S. Environmental Protection Agency, 2010) and BBS starting locations.

including generalist $(\mathrm{n}=32)$, woodland $(\mathrm{n}=22)$, wetland $(\mathrm{n}=7)$, grassland $(\mathrm{n}=13)$ and shrubland $(\mathrm{n}=9)$ (Appendix A, Table A1). We chose to conduct this study at the habitat guild level as a starting point to identify if changes in land cover (i.e. changes in habitat) influences regional-scales patterns in bird communities. This type of design has been shown to be a good method of examining biodiversity (Noss, 1990; Tilman, 1994; Watson et al., 2004).

\subsection{Data analyses}

\subsubsection{Quantification of land cover change across entire study area}

To identify land cover change, we calculated the number of all pixels that were classified as grassland first and converted to another land cover type within the 10-year period (e.g. grassland to cropland) per ecoregion (Omernik, 1995). There are eight possible conversions that could take place; one for each cover type that grasslands could be converted to, based on our broad land cover categories. To quantify land cover dynamics for the 10-year period, we calculated total coverage of each land cover type $\left(\mathrm{km}^{2}\right)$ in each year. Thereafter, using only pixels that were classified as grasslands in 2006 or later (without any previous land cover conversion), we calculated the number of subsequent changes undergone in these pixels. In other words, the number of changes that a pixel has undergone since it was first classified as grassland. For example, a pixel can be classified as grassland from 2006 to 2008, then as cropland from 2009 to 2010, then as woodland from 2011 to 2015. This would be quantified as two land cover changes. If the same pixel was converted back to grassland in 2015 after it was converted to woodland (e.g. 2011-2014 instead of 2011-2015), this would be quantified as three changes i.e. the first change is from grassland to cropland, the second change from cropland to woodland and the third change from woodland to grassland. This was used to identify the majority land cover change and how much grassland area was lost per ecoregion over the 10-year period.

2.3.2. Changes in avian population dynamics in response to land cover change

An occupancy model was developed for each species. Occupancy is defined as the probability with which a species is observed at site $\mathrm{s}$ 
during time $t+1$, given it was found at time $t$, at site s (MacKenzie et al., 2003). Occupancy models allow the estimation of the change in species' occurrences by explicitly estimating the dynamic processes of colonization and extinction from detection/non-detection survey data (MacKenzie, 2006). However, most species are observed imperfectly (i.e., they may be present during a survey at a site but are not detected). Failing to account for detection probability (i.e. analogous to taking a logistic regression approach) leads to biases in occupancy estimates and subsequent research and management conclusions (Johnson et al., 2013; MacKenzie, 2006; Royle et al., 2012). Occupancy models allow for estimation of detection probability, which can be used to generate a less biased estimate of occupancy probability (Kéry, 2011). Occupancy models make use of detection/non-detection data, but repeat surveys and detection histories for each point are required to calculate detection probability (MacKenzie, 2006; MacKenzie et al., 2003).

Dynamic occupancy models are extensions of standard occupancy models that allow for estimation of the dynamic components of occupancy (colonization and extinction of a species) over each site. Colonization is defined as the probability of an unoccupied site at time $t$ becoming occupied at the subsequent visit (time $t+1$ ). Extinction is defined as the probability of an occupied site at time $t$ becoming unoccupied at the subsequent (time $t+1$ ) (MacKenzie et al., 2003). Assumptions of dynamic occupancy models are not as strict as for standard occupancy models; whereas standard occupancy models assume a closed population over the entire study period-an assumption that is usually violated (Rota et al., 2009)-dynamic occupancy models only assume a closed population during the survey period and is most inappropriate when considering rare or declining species. For our analysis, we assumed a closed population as we did not include rare or declining species. Our primary survey period was 10 years, and our secondary sampling period was the single survey on each route in each year.

Dynamic occupancy models were used to estimate the rates of colonization (gamma) and extinction (epsilon) as well as occupancy rates (psi) for each species. Results for each dynamic component are reported by habitat guild. Initial inspection of covariate data showed that the vast majority of land cover surrounding survey points were composed of cropland, grassland and woodland ( $>90 \%$ of all total land cover). Therefore, our occupancy models only included these land cover types. We also included year as a variable in the detection (p) component of the occupancy models to account for potential bias related to variation among years. We did not possess observer identity information although most observations were performed under "Run Protocol" type 101 (Pardieck et al., 2014; Sauer et al., 2014). This is described as "3min, 1 observer, single run per year" and most of the data used (99.93\%) were recorded under this protocol. We were most interested in extinction and colonization as a function of changes in the proportion of cropland, grassland and woodland at each site (Table 1). Furthermore, to be able to compare extinction and colonization rates between species, all covariates were standardized prior to running the occupancy analyses.

\section{Table 1}

Modeling parameters for each species $s$ over sites $i$ was fit by components 1-4. Cropland, grassland and woodland refer to the proportion of land cover at each site per survey year and make up $>90 \%$ of the land cover per site.

Data sourced from cropscape.org.

\begin{tabular}{lll}
\hline $\begin{array}{l}\text { Component } \\
\text { number }\end{array}$ & Component & Model parameters \\
\hline 1 & $\begin{array}{l}\text { Initial } \\
\text { occupancy } \\
(\Psi)_{s}\end{array}$ & $\begin{array}{l}\sim \beta_{0}+\beta_{1} * \text { Cropland }_{i}+\beta_{2} * \text { Grassland }_{i}+\beta_{3} * \\
\text { Woodland }_{i}\end{array}$ \\
& $\begin{array}{l}\text { Colonization } \\
(\gamma)_{s}\end{array}$ & $\sim \beta_{0}+\beta_{1} *$ Cropland $_{i}+\beta_{2} *$ Grassland $_{i}+\beta_{3} *$ \\
& Woodland $_{i}+\beta_{4} *$ Year $_{i}$ \\
3 & Extinction $(\varepsilon)_{s}$ & $\sim \beta_{0}+\beta_{1} *$ Cropland $_{i}+\beta_{2} *$ Grassland $_{i}+\beta_{3} *$ \\
& Woodland $_{i}+\beta_{4} *$ Year $_{i}$ \\
4 & Detection $(\delta)_{s}$ & $\sim \beta_{0} *$ Year $_{i}$ \\
\hline
\end{tabular}

All parameters (psi, gamma, epsilon and p) were modeled with binomial distributions (logit link) in R v3.2.0 ( $\mathrm{R}$ Development Core Team, 2015) using the package unmarked (Fiske and Chandler, 2011) and results were plotted with ggplot2 (Wickham, 2009). We ran Bayesian meta-analyses in R using the R2WinBugs package (Sturtz et al., 2005) and program winBUGs (Lunn et al., 2000) to estimate average gamma (colonization) and epsilon (extinction), along with 95\% credible intervals (CI), for each habitat guild (McCarthy and Masters, 2005). This allowed us to estimate the mean response for both dynamic components, which is weighted by the inverse of its standard error, while accounting for the variance around the species-level mean beta estimates. This approach allows a higher weighting to samples with a smaller standard error, and a lower weighting to samples with a larger standard error. The basic structure of this model was similar to a regular linear mixed effects model, with habitat guild as a random factor and normally distributed errors. However, instead of treating the mean colonization and extinction estimates as without error, we modeled these components from a normal distribution using the means and standard errors as estimated by the occupancy models. Where habitat guild coefficients (e.g. gamma and epsilon) and their CI overlap zero, there was no support for the relationship between the mean gamma/epsilon rate and the land cover variable. For the Bayesian analysis, we used non-informative priors and ran 3 chains over 50,000 iterations with a burn-in of 25,000 iterations and a thinning period of 5 . The WinBUGS code is provided in Appendix A.

\section{Results}

\subsection{Quantification of land cover change across entire study area}

The number of land cover transitions observed at the pixel level ranged from zero to eight over the 10-year period (Fig. 2). The total initial grasslands area in 2006 covered $\sim 159,600 \mathrm{~km}^{2}$, of which $34,400 \mathrm{~km}^{2}$ were converted to some other land cover type, where most $\left(\sim 31,000 \mathrm{~km}^{2}\right)$ were converted to cropland by 2015 . The remaining $3400 \mathrm{~km}^{2}$ area were mostly converted to woodland (Table 2). Of the 19 Level 3 ecoregions within the study area, the Middle Rockies ecoregion experienced the greatest proportional grassland loss $(\sim 17 \%$; $171 \mathrm{~km}^{2}$ ), with all loss due to woodland expansion (Table 2). However, the highest absolute area of grassland loss occurred in the Central Great Plains ecoregion $\left(11,544 \mathrm{~km}^{2}\right)$ and was primarily due to cropland expansion (12.23\%). The highest numbers of land cover changes per pixel were observed in the Central Great Plains and the Northwestern Great Plains (Table 2). Certain areas (e.g. Nebraska Sand Hills, the Flint Hills and western parts of South Dakota and Oklahoma) experienced the least land cover changes at the $3 \mathrm{~km}^{2}$ scale (Fig. 2).

\subsection{Changes in avian population dynamics in response to land cover change}

Responses in the population dynamics of birds in response to changes in the proportion of cropland, grassland and woodland over time displayed substantial within-habitat guild variation-including both positive and negative responses for both colonization (gamma) and extinction (epsilon) rates (Appendix A, Figs. A1-3). We found no significant associations in colonization dynamics of birds per habitat guild as a function of proportional change in cropland. In contrast, mean extinction rates for all guilds had a significant negative relationship with change in cropland proportion (Table 3). Average colonization rates for both generalist and grassland birds related to change in grassland proportion was not significant. Furthermore, only shrubland birds had a significant negative extinction response as a function of grassland increase (Table 3). Species-level responses as a function of changes in woodland proportion also showed high variation in both dynamic components (Appendix A, Fig. A3). We also found no significant associations in colonization between bird habitat guilds and proportional change in woodlands. However, extinction rate of shrubland birds was negatively 


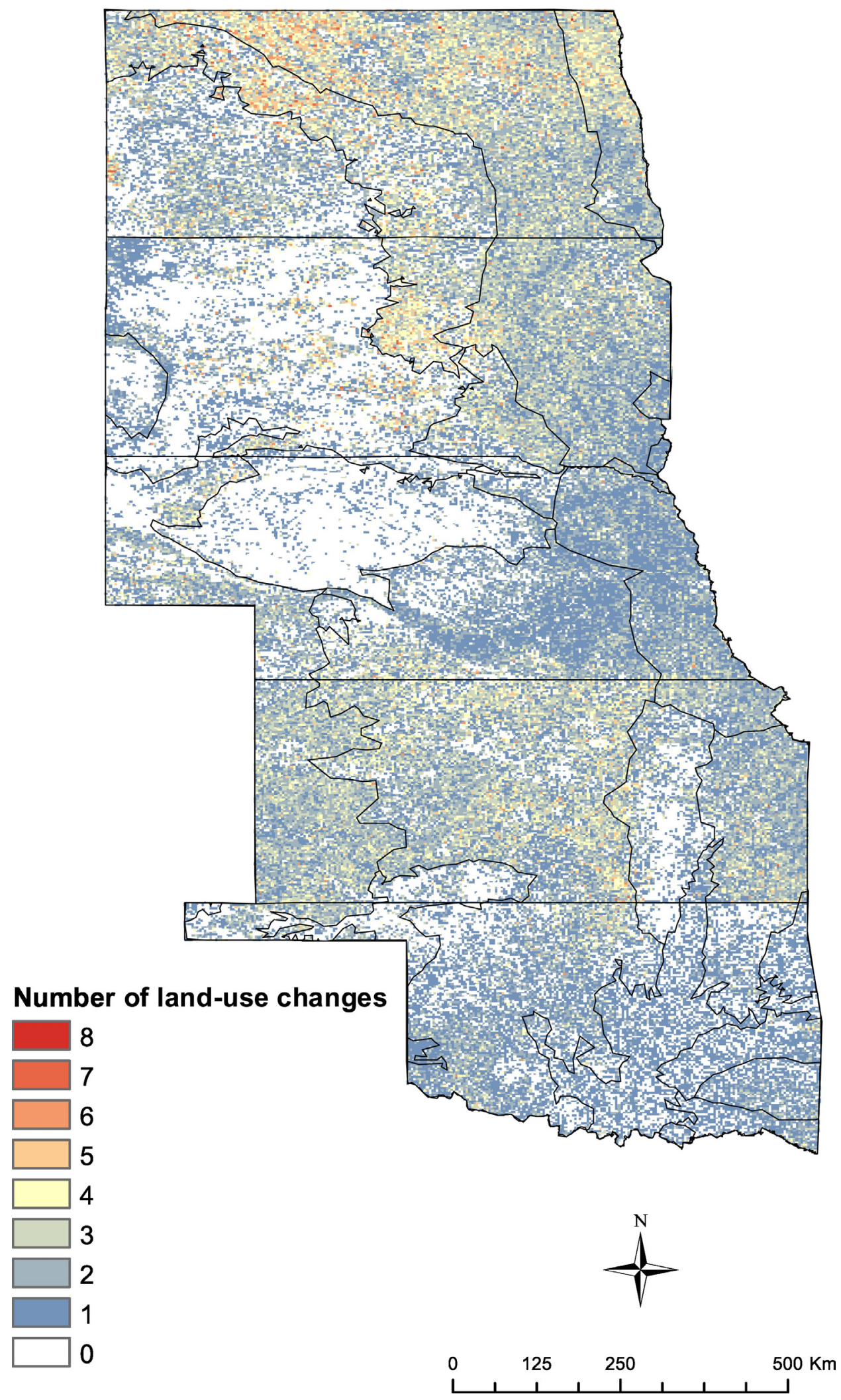

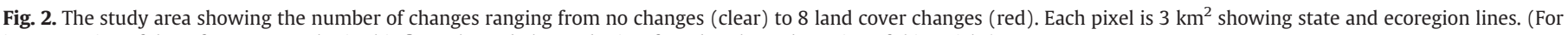
interpretation of the references to color in this figure legend, the reader is referred to the web version of this article.)

related to changes in woodland cover (i.e., increased woodland cover tended to decrease extinction rates of shrubland birds). Overall, extinction rates of all guilds showed negative responses to cropland, and extinction rates of shrubland species showed negative responses to grassland and woodland.

\section{Discussion}

Our main goals for the study were to highlight spatiotemporal patterns in land cover between 2006 and 2015, and whether these regional changes influence breeding bird range dynamics. Our results show a 
Table 2

The proportion and area of each ecoregion within the study area initially classified as grasslands and permanently converted to another cover type within the 10-year period.

\begin{tabular}{|c|c|c|c|c|c|}
\hline Ecoregion & $\begin{array}{l}\% \text { study } \\
\text { area }\end{array}$ & $\begin{array}{l}\text { Grassland lost } \\
\left(\text { area } \mathrm{km}^{2}\right)\end{array}$ & $\begin{array}{l}\text { Number of land types grasslands } \\
\text { were lost to }\end{array}$ & $\begin{array}{l}\text { Most abundant land type change } \\
\text { from grasslands }\end{array}$ & $\begin{array}{l}\% \text { most abundant land type change } \\
\text { from grasslands }\end{array}$ \\
\hline Central Great Plains & 23.34 & 11,544 & 8 & Cropland & 12.23 \\
\hline Northwestern Great Plains & 15.95 & 4122 & 8 & Cropland & 5.58 \\
\hline Aspen Parkland/Northern Glaciated Plains & 12.86 & 4221 & 4 & Cropland & 9.52 \\
\hline High Plains & 9.19 & 2250 & 5 & Cropland & 6.66 \\
\hline Northwestern Glaciated Plains & 8.08 & 3027 & 6 & Cropland & 10.44 \\
\hline Nebraska Sand Hills & 6.06 & 648 & 6 & Cropland & 3.01 \\
\hline Western Corn Belt Plains & 4.94 & 1101 & 4 & Cropland & 5.44 \\
\hline Central Irregular Plains & 4.43 & 2034 & 3 & Cropland & 6.50 \\
\hline Cross Timbers & 3.69 & 1995 & 6 & Woodland & 13.30 \\
\hline Flint Hills & 2.86 & 891 & 3 & Cropland & 6.08 \\
\hline Southwestern Tablelands & 1.88 & 690 & 5 & Cropland & 6.25 \\
\hline Lake Manitoba and Lake Agassiz Plain & 1.87 & 486 & 3 & Cropland & 7.29 \\
\hline Arkansas Valley & 1.28 & 513 & 4 & Woodland & 10.48 \\
\hline Ouachita Mountains & 1.09 & 111 & 5 & Woodland & 2.29 \\
\hline Middle Rockies & 0.82 & 171 & 3 & Woodland & 16.54 \\
\hline South Central Plains & 0.70 & 261 & 5 & Woodland & 9.23 \\
\hline Ozark Highlands & 0.64 & 234 & 3 & Woodland & 9.38 \\
\hline Boston Mountains & 0.22 & 36 & 4 & Woodland & 4.18 \\
\hline East Central Texas Plains & 0.09 & 57 & 3 & Woodland & 14.71 \\
\hline
\end{tabular}

substantial amount of land cover conversion over the scale of the entire U.S. Great Plains. The biggest threat to grassland persistence was cropland conversion followed by woodland expansion (Table 2), a finding echoing recent reports (WWF, 2016). In Europe, changing management intensity of grassland such as increasing use of inorganic nitrogen, planting silage instead of hay and intensification in certain cereal grains and seeds has had a detrimental impact on grassland birds (Vickery et al., 2001; Vickery et al., 1995; Wilson et al., 1999). These changes have reduced food resources, habitat and breeding suitability for birds. Our study highlights how similar regional scale changes in land cover can influence breeding bird colonization and extinction rates in the Great Plains, USA.

Along with the documented increases in woodlands (Berg et al., 2015), we provide additional evidence that a large proportion of agricultural expansion exists at the cost of grasslands (Auch et al., 2011). Even though the Great Plains is one of the most heavily cropped areas in North America (Ostlie and Haferman, 1999), the area still contains ecosystem processes such as fire and is home to many native plant and animal communities (Samson et al., 2004). However, the vast majority of unconverted grassland has been restricted to ecoregions within the Great Plains (e.g. the Flint Hills, the Nebraska Sand Hills as seen in Fig. 2). A major conservation concern surrounding woodland expansion is the new challenge its presents for preserving native grasslands (Twidwell et al., 2015). Nevertheless, the observed spatiotemporal dynamics in land cover promotes a range of habitat types within the landscape matrix, which has implications for bird habitats.

Grassland birds have shown to respond both positively and negatively to the presence and type of neighboring agricultural lands and habitat fragmentation (Blank et al., 2016; Herkert, 1994; Whittingham and Evans, 2004). However, their response to woodland encroachment has been detrimental in both richness and abundance (Coppedge et al., 2001; Rosenstock and Charles Van Riper, 2001). Given the concern surrounding woodland encroachment in grasslands (Wessman et al., 2012), cropland expansion poses an additional threat to the grassland bird community (Chapman et al., 2004b). Croplands and pasturelands play an important role in human livelihoods (Foley et al., 2005) and our study shows that there is a prevailing trend to these cover types as dominant land cover in our study area over the past 10 years (Table 2).

The overall colonization effect for all guilds as a function of cropland was not significant (Table 3). Nevertheless, species-level variation was apparent, i.e. certain species estimates (for both colonization and extinction) were significantly negatively influenced by cropland, while others were positively influenced by cropland. This suggests that certain species display high utilization of surrounding land cover types within the landscape matrix (Andren, 1994; Schulte et al., 2016; Sparks et al., 1996). Some examples of these species include Dickcissel (Spiza americana), which showed a significant positive gamma response to cropland proportion, while a few others, such as Grasshopper Sparrow (Ammodramus savannarum), Northern Harrier (Circus cyaneus) and Swainsons Hawk (Buteo swainsoni), had a significant negative epsilon response to the proportion of cropland. These species-level results, especially for Grasshopper Sparrows, may seem non-intuitive (e.g. these species are thought to be habitat specialists). Nevertheless, our study suggests that at regional scales, certain species can utilize other land cover types, whether directly for food or indirectly, e.g. prey associated with a specific crop. Vickery et al. (2001) showed that fertilized crops in Europe, which tend to be fast-growing, provide different feeding and nesting habitat for birds. Considering that the Great Plains region has a large proportion occupied by cultivated crops such as wheat and corn (Han et al., 2012; Homer et al., 2015), habitat diversity is constantly threatened by increasing cropland in the region. Current rates of grassland conversion were documented at $2 \%$ annually between 2009 and 2015 (WWF, 2016). This in turn may have a significant impact on ecosystem services such as $\mathrm{CO}_{2}$ sequestration and soil erosion. While cropland expansion may not seem to be detrimental for any habitat guild at regional scales, indeed it poses a threat to specific species (Appendix A, Fig. A1) and agrees with other reports (North America Bird Conservation Initiative, 2016).

Habitat-guild gamma responses as a function to the proportion of grassland were also non-significant. There were a number of guilds (shrubland, wetland and woodland) that had negative gamma estimates, while grassland and generalists guilds had a mean positive gamma estimate. For the mean epsilon estimates, all epsilon estimates were negative, but only the estimate for the shrubland guild was significant. This negative association as a function of grassland proportion suggests that species making up the shrubland guild can utilize other land cover types available. In contrast, only species-level variation produced significant effects to the proportion of woodland. Here, the same group of species that produced a significant gamma and epsilon response as a function of cropland proportion, had a significant specieslevel response as a function of woodland proportion. Dickcissel showed a significant positive gamma response as a function of woodland expansion. While this may be uncommon for this species (Hughes et al., 1999), it suggests they can utilize various land cover types within the 
Table 3

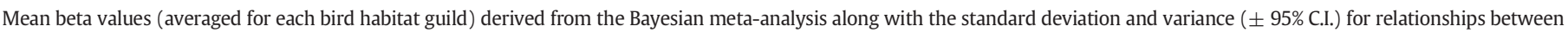

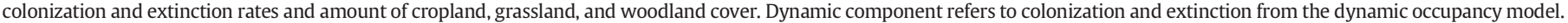
$\mathrm{Col}=$ colonization. Ext $=$ Extinction.

\begin{tabular}{|c|c|c|c|c|c|c|}
\hline & \multirow[t]{2}{*}{ Habitat guild } & \multicolumn{5}{|c|}{ Colonization $(\gamma)$} \\
\hline & & mean & s.d. & $2.5 \%$ & $50 \%$ & $97.5 \%$ \\
\hline \multirow[t]{12}{*}{ Cropland $\left(\beta_{1}\right)$} & Generalist $(\mathrm{n}=32)$ & 0.064 & 0.081 & -0.880 & 0.591 & 0.232 \\
\hline & Grassland $(\mathrm{n}=13)$ & 0.161 & 0.140 & -0.068 & 0.151 & 0.461 \\
\hline & Shrubland $(\mathrm{n}=9)$ & -0.188 & 0.182 & -0.595 & -0.159 & 0.087 \\
\hline & Wetland $(\mathrm{n}=7)$ & -0.004 & 0.146 & -0.313 & -0.154 & 0.286 \\
\hline & Woodland $(\mathrm{n}=22)$ & $\begin{array}{l}-0.159 \\
\text { Extinctio }\end{array}$ & 0.108 & -0.379 & -0.153 & 0.023 \\
\hline & Generalist $^{*}(\mathrm{n}=32)$ & -0.296 & 0.097 & -0.481 & -0.297 & -0.105 \\
\hline & Grassland* $(\mathrm{n}=13)$ & -0.401 & 0.163 & -0.726 & -0.402 & -0.082 \\
\hline & Shrubland* $(\mathrm{n}=9)$ & -0.720 & 0.201 & -1.118 & -0.722 & -0.331 \\
\hline & Wetland* $(\mathrm{n}=7)$ & -0.145 & 0.200 & -0.611 & -0.140 & -0.238 \\
\hline & Woodland* $(\mathrm{n}=22)$ & -0.362 & 0.125 & -0.610 & -0.365 & -0.110 \\
\hline & & \multicolumn{5}{|c|}{ Colonization $(\gamma)$} \\
\hline & & mean & s.d. & $2.5 \%$ & $50 \%$ & $97.5 \%$ \\
\hline \multirow[t]{13}{*}{ Grassland $\left(\beta_{2}\right)$} & Generalist $(\mathrm{n}=32)$ & 0.094 & 0.079 & -0.047 & 0.092 & 0.256 \\
\hline & Grassland $(n=13)$ & 0.202 & 0.135 & -0.018 & -0.194 & 0.484 \\
\hline & Shrubland $(\mathrm{n}=9)$ & -0.047 & 0.124 & -0.306 & -0.039 & 0.188 \\
\hline & Wetland $(\mathrm{n}=7)$ & -0.005 & 0.135 & -0.278 & -0.004 & 0.278 \\
\hline & Woodland $(\mathrm{n}=22)$ & -0.122 & 0.092 & -0.309 & -0.118 & 0.043 \\
\hline & & Extinctio & & & & \\
\hline & Generalist $(\mathrm{n}=32)$ & -0.048 & 0.093 & -0.231 & -0.049 & 0.136 \\
\hline & Grassland $(n=13)$ & -0.255 & 0.160 & -0.571 & -0.254 & 0.043 \\
\hline & Shrubland* $(\mathrm{n}=9)$ & -0.538 & 0.235 & -0.981 & -0.541 & -0.053 \\
\hline & Wetland $(\mathrm{n}=7)$ & -0.002 & 0.172 & -0.343 & -0.003 & 0.350 \\
\hline & Woodland $(\mathrm{n}=22)$ & -0.006 & 0.113 & -0.230 & -0.007 & 0.223 \\
\hline & & \multicolumn{5}{|c|}{ Colonization $(\gamma)$} \\
\hline & & mean & s.d. & $2.5 \%$ & $50 \%$ & $97.5 \%$ \\
\hline \multirow[t]{11}{*}{ Woodland $\left(\beta_{3}\right)$} & Generalist $(\mathrm{n}=32)$ & -0.024 & 0.066 & -0.158 & -0.021 & 0.105 \\
\hline & Grassland $(\mathrm{n}=13)$ & -0.157 & 0.129 & -0.425 & -0.147 & 0.051 \\
\hline & Shrubland $(\mathrm{n}=9)$ & -0.071 & 0.123 & -0.342 & -0.055 & 0.149 \\
\hline & Wetland $(n=7)$ & -0.095 & 0.136 & -0.400 & -0.077 & 0.138 \\
\hline & Woodland $(\mathrm{n}=22)$ & -0.142 & 0.098 & -0.341 & -0.140 & 0.025 \\
\hline & & \multicolumn{5}{|c|}{ Extinction $(\varepsilon)$} \\
\hline & Generalist $(\mathrm{n}=32)$ & -0.104 & 0.091 & -0.284 & -0.104 & 0.071 \\
\hline & Grassland $(\mathrm{n}=13)$ & 0.170 & 0.137 & -0.084 & 0.166 & 0.456 \\
\hline & Shrubland* $(\mathrm{n}=9)$ & -0.444 & 0.215 & -0.867 & -0.445 & -0.028 \\
\hline & Wetland $(\mathrm{n}=7)$ & 0.243 & 0.179 & -0.079 & 0.236 & 0.612 \\
\hline & Woodland $(\mathrm{n}=22)$ & -0.128 & 0.113 & -0.360 & -0.125 & 0.084 \\
\hline
\end{tabular}

* Denotes significance at $\alpha=5 \%$.

landscape matrix and may adapt to woodland expansion to a certain degree. Other species such as Bobolink (Dolichonyx oryzivorus) and Grasshopper Sparrow and Vesper Sparrow (Pooecetes gramineus) had negative gamma estimates suggesting woodland expansion would be detrimental for these species. Furthermore, the shrubland guild maintained a significant epsilon response to woodland proportion suggesting species making up the shrubland guild are well adapted to areas increasing in woodland proportion. Overall, our study highlights that the current landscape matrix and the changes associated with it, highly favors shrubland birds.

Overall, our study highlights that certain land cover changes favors some habitat guilds more than others, and this may be exacerbated in disturbance-driven ecosystems where fire plays a big role in the preservation of grasslands (Fraterrigo and Rusak, 2008). Land-use change in an area can be driven by a number of factors such as a combination of policy and socioeconomic factors (Drummond, 2007; Searchinger et al., 2008) and the consequences for biodiversity are seldom quantified. Landscapes such as the Great Plains (e.g. areas with flat terrain and nutrient-rich soils) are prone to intensive agriculture (Matson et al., 1997) and given human population supply and demand needs, we suspect that the region may become increasingly intensified (WWF, 2016). Nevertheless, the cascading effects of land-use intensification may be scale- specific. Wilson et al. (1999) highlighted the importance of agricultural grassland alongside tilled land as a source of invertebrate food for breeding birds. Similarly, when "prairie strips" were incorporated into annual row crops, bird abundance, species richness and diversity responded positively (Schulte et al., 2016). Therefore, the distribution and spatial arrangement of various land cover types within the landscape matrix is essential to maintain diversity (Duflot et al., 2015; Fahrig et al., 2011; Flather and Sauer, 1996; Fuhlendorf and Engle, 2001). Other studies have alluded to this observation as well; landscape composition (e.g. a mixture of juniperus species and mixed woodland) was the most important factor for higher occupancy and density estimates of Golden-cheeked warblers (Reidy et al., 2016).

A caveat of our study was that spatial information on land cover types for our region is short and recent. We would have preferred to assess longer-term trends in breeding birds within the region, specifically since woodland encroachment has been documented in certain areas prior to 2006 (the year from which we measured landscape-change based on data availability). Therefore, we acknowledge that the time period considered might not have captured major changes in land cover, particularly with the resurgence of grasslands correlated with the Conservation Reserve Program (Dunn et al., 1993). Nevertheless, our study shows that bird communities can respond to shorter-term land cover 
changes which influences habitat (Parody et al., 2001; Radford and Bennett, 2007).

\subsection{Conclusions}

It is clear that understanding the biological consequences of land cover changes, whether natural or anthropogenic remains a challenge for grassland conservation. However, we provide support that the certain birds (e.g. shrubland birds) can adapt to their local conditions and maximize benefit from major land cover changes. We did not detect major responses by grassland birds to cropland and woodland expansion at regional scales. One reason for the lack of major responses in grassland birds may be related to scale, both in land cover and species-level data, which was aimed at broad, regional scales. We therefore suggest that future research considers fine scaled land cover data to match species-level responses within community-level dynamics as key indicators for biodiversity monitoring in areas prone to land cover change. Nevertheless, the apparent favorable land cover conditions for shrubland species may be related to early stages of woodland expansion. Therefore, the importance of the landscape matrix arrangement and its constituents is paramount, considering that increases in grasslands and croplands generally relates to habitat loss for woodland and wetland bird communities (Naugle et al., 2001; Serran and Creed, 2016; Wright and Wimberly, 2013), yet favors grassland and generalist birds. It is therefore suspected that adaptations to the available food supply, such as direct dependence on crop types for seeds for granivores, or indirect dependence via food items like insects for insectivorous species that respond to various crops (Fuller, 2000), will indeed enhance certain species persistence while cropland expansion will be detrimental for others. Therefore, since grassland birds are in decline in North America (North America Bird Conservation Initiative, 2016), careful consideration should be taken with regards to future cropland expansion efforts (Fuller et al., 1995) particularly in light of woodland encroachment.

\section{Acknowledgements}

The authors would like to thank Drs. Evan Tanner and Scott Loss for their useful comments on earlier drafts of this manuscript. This research was funded by the National Science Foundation ESPCoR Grant (Award No. OIA-1301789) and the Coupled Human Natural Systems project (Award No. DEB-1413900).

\section{References}

Andren, H., 1994. Effects of habitat fragmentation on birds and mammals in landscapes with different proportions of suitable habitat: a review. Oikos 355-366.

Auch, R.F., Sayler, K.L., Napton, D.E., Taylor, J.L., Brooks, M.S., 2011. Ecoregional differences in late-20th-century land-use and land-cover change in the US northern great plains. Great Plains Res. 21, 231-243.

Berg, M.D., Sorice, M.G., Wilcox, B.P., Angerer, J.P., Rhodes, E.C., Fox, W.E., 2015. Demographic changes drive woody plant cover trends-an example from the great plains. Rangel. Ecol. Manag. 68, 315-321.

Bestelmeyer, B.T., Briske, D.D., 2012. Grand challenges for resilience-based management of Rangelands. Rangel. Ecol. Manag. 65, 654-663.

Blank, P.J., Williams, C.L., Sample, D.W., Meehan, T.D., Turner, M.G., 2016. Alternative scenarios of bioenergy crop production in an agricultural landscape and implications for bird communities. Ecol. Appl. 26, 42-54.

Bled, F., Sauer, J., Pardieck, K., Doherty, P., Royle, J.A., 2013. Modeling trends from North American Breeding Bird Survey data: a spatially explicit approach. PLoS One 8, e81867.

Briske, D.D., Fuhlendorf, S.D., Smeins, F.E., 2003. Vegetation dynamics on rangelands: a critique of the current paradigms. J. Appl. Ecol. 40, 601-614.

Briske, D.D., Fuhlendorf, S.D., Smeins, F., 2005. State-and-transition models, thresholds, and rangeland health: a synthesis of ecological concepts and perspectives. Rangel. Ecol. Manag. 58, 1-10.
Chapman, R.N., Engle, D.M., Masters, R.E., Leslie Jr., D.M., 2004a. Grassland vegetation and bird communities in the southern Great Plains of North America. Agric. Ecosyst. Environ. 104, 577-585.

Chapman, R.N., Engle, D.M., Masters, R.E., Leslie Jr., D.M., 2004b. Tree invasion constrains the influence of herbaceous structure in grassland bird habitats. Ecoscience 11, 55-63.

Clark, J.S., Grimm, E.C., Donovan, J.J., Fritz, S.C., Engstrom, D.R., Almendinger, J.E., 2002. Drought cycles and landscape responses to past aridity on prairies of the northern Great Plains, USA. Ecology 83, 595-601.

Coppedge, B.R., Engle, D.M., Masters, R.E., Gregory, M.S., 2001. Avian response to landscape change in fragmented southern Great Plains grasslands. Ecol. Appl. 11, 47-59.

Davis, C.A., Churchwell, R.T., Fuhlendorf, S.D., Engle, D.M., Hovick, T.J., 2016. Effect of pyric herbivory on source-sink dynamics in grassland birds. J. Appl. Ecol.

Drummond, M.A., 2007. Regional dynamics of grassland change in the western Great Plains. Great Plains Res. 133-144.

Duflot, R., Aviron, S., Ernoult, A., Fahrig, L., Burel, F., 2015. Reconsidering the role of 'seminatural habitat'in agricultural landscape biodiversity: a case study. Ecol. Res. 30, $75-83$.

Dunn, C.P., Stearns, F., Guntenspergen, G.R., Sharpe, D.M., 1993. Ecological benefits of the conservation reserve program. Conserv. Biol. 7, 132-139.

Ehrlich, P., Dobkin, D.S., Wheye, D., 1988. The Birder's Handbook: A Field Guide to the Natural History of North American Birds. Simon and Schuster.

Engle, D.M., Coppedge, B.R., Fuhlendorf, S.D., 2008. From the dust bowl to the green glacier: human activity and environmental change in Great Plains grasslands. Western North American Juniperus Communities. Springer, pp. 253-271.

Fahrig, L., Baudry, J., Brotons, L., Burel, F.G., Crist, T.O., Fuller, R.J., Sirami, C., Siriwardena, G.M., Martin, J.L., 2011. Functional landscape heterogeneity and animal biodiversity in agricultural landscapes. Ecol. Lett. 14, 101-112.

Fargione, J.E., Cooper, T.R., Flaspohler, D.J., Hill, J., Lehman, C., Tilman, D., McCoy, T. McLeod, S., Nelson, E.J., Oberhauser, K.S., 2009. Bioenergy and wildlife: threats and opportunities for grassland conservation. Bioscience 59, 767-777.

Fischer, J., Batáry, P., Bawa, K.S., Brussaard, L., Chappell, M.J., Clough, Y., Daily, G.C., Dorrough, J., Hartel, T., Jackson, L.E., 2011. Conservation: limits of land sparing. Science 334, 593.

Fischer, J., Abson, D.J., Butsic, V., Chappell, M.J., Ekroos, J., Hanspach, J., Kuemmerle, T., Smith, H.G., Wehrden, H., 2014. Land sparing versus land sharing: moving forward. Conserv. Lett. 7, 149-157.

Fiske, I., Chandler, R., 2011. Unmarked: an R package for fitting hierarchical models of wildlife occurrence and abundance. J. Stat. Softw. 43, 1-23.

Flather, C.H., Sauer, J.R., 1996. Using landscape ecology to test hypotheses about largescale abundance patterns in migratory birds. Ecology 77, 28-35.

Foley, J.A., DeFries, R., Asner, G.P., Barford, C., Bonan, G., Carpenter, S.R., Chapin, F.S., Coe, M.T., Daily, G.C., Gibbs, H.K., 2005. Global consequences of land use. Science 309, 570-574.

Fraterrigo, J.M., Rusak, J.A., 2008. Disturbance-driven changes in the variability of ecological patterns and processes. Ecol. Lett. 11, 756-770.

Fuhlendorf, S.D., Engle, D.M., 2001. Restoring heterogeneity on rangelands: ecosystem management based on evolutionary grazing patterns. Bioscience 51, 625-632.

Fuhlendorf, S.D., Smeins, F.E., Grant, W.E., 1996. Simulation of a fire-sensitive ecological threshold: a case study of Ashe juniper on the Edwards Plateau of Texas, USA. Ecol. Model. 90, 245-255.

Fuhlendorf, S.D., Harrell, W.C., Engle, D.M., Hamilton, R.G., Davis, C.A., Leslie Jr., D.M., 2006 Should heterogeneity be the basis for conservation? Grassland bird response to fire and grazing. Ecol. Appl. 16, 1706-1716.

Fuller, R.J., 2000. Relationships between recent changes in lowland British agriculture and farmland bird populations: an overview. Ecology and Conservation of Lowland Farmland Birds, pp. 5-16.

Fuller, R., Gregory, R., Gibbons, D., Marchant, J., Wilson, J., Baillie, S., Carter, N., 1995 Population declines and range contractions among lowland farmland birds in Britain. Conserv. Biol. 9, 1425-1441.

Gregory, R., Noble, D., Field, R., Marchant, J., Raven, M., Gibbons, D., 2003. Using birds as indicators of biodiversity. Ornis Hungarica 12, 11-24.

Gregory, R.D., Willis, S.G., Jiguet, F., Vořǐššek, P., Klvaňová, A., van Strien, A., Huntley, B., Collingham, Y.C., Couvet, D., Green, R.E., 2009. An indicator of the impact of climatic change on European bird populations. PLoS One 4, e4678.

Gutzwiller, K.J., Riffell, S.K., Flather, C.H., 2015. Avian abundance thresholds, human-altered landscapes, and the challenge of assemblage-level conservation. Landsc. Ecol. 30, 2095-2110.

Han, W., Yang, Z., Di, L., Mueller, R., 2012. CropScape: a Web service based application for exploring and disseminating US conterminous geospatial cropland data products for decision support. Comput. Electron. Agric. 84, 111-123.

Heisler, J.L., Briggs, J.M., Knapp, A.K., 2003. Long-term patterns of shrub expansion in a C4-dominated grassland: fire frequency and the dynamics of shrub cover and abundance. Am. J. Bot. 90, 423-428.

Herkert, J.R., 1994. The effects of habitat fragmentation on midwestern grassland bird communities. Ecol. Appl. 4, 461-471.

Hobbs, N.T., Galvin, K.A., Stokes, C.J., Lackett, J.M., Ash, A.J., Boone, R.B., Reid, R.S., Thornton, P.K., 2008. Fragmentation of rangelands: Implications for humans, animals, and landscapes. Glob. Environ. Chang. 18, 776-785.

Homer, C., Dewitz, J., Yang, L., Jin, S., Danielson, P., Xian, G., Coulston, J., Herold, N., Wickham, J., Megown, K., 2015. Completion of the 2011 National Land Cover Database for the conterminous United States-representing a decade of land cover change information. Photogramm. Eng. Remote Sens. 81, 345-354.

Howland, B.W., Stojanovic, D., Gordon, I.J., Radford, J., Manning, A.D., Lindenmayer, D.B., 2016. Birds of a feather flock together: using trait-groups to understand the effect of macropod grazing on birds in grassy habitats. Biol. Conserv. 194, 89-99. 
Hughes, J.P., Robel, R.J., Kemp, K.E., Zimmerman, J.L., 1999. Effects of habitat on Dickcissel abundance and nest success in Conservation Reserve Program fields in Kansas. J. Wildl. Manag. 523-529.

Johnson, D.S., Conn, P.B., Hooten, M.B., Ray, J.C., Pond, B.A., 2013. Spatial occupancy models for large data sets. Ecology 94, 801-808.

Keeley, J.E., 2009. Fire intensity, fire severity and burn severity: a brief review and suggested usage. Int. J. Wildland Fire 18, 116-126.

Kéry, M., 2011. Towards the modelling of true species distributions. J. Biogeogr. 38 617-618.

Knopf, F.L., Samson, F.B., 1994. Scale perspectives on avian diversity in western riparian ecosystems. Conserv. Biol. 8, 669-676.

Lauenroth, W., Burke, I.C., Gutmann, M.P., 1999. The structure and function of ecosystems in the central North American grassland region. Great Plains Res. 223-259.

Liu, W., Gopal, S., Woodcock, C.E., 2004. Uncertainty and confidence in land cover classification using a hybrid classifier approach. Photogramm. Eng. Remote Sens. 70, 963-971.

Lunn, D.J., Thomas, A., Best, N., Spiegelhalter, D., 2000. WinBUGS-a Bayesian modelling framework: concepts, structure, and extensibility. Stat. Comput. 10, 325-337.

MacKenzie, D.I., 2006. Occupancy Estimation and Modeling: Inferring Patterns and Dynamics of Species Occurrence. Elsevier Science \& Tech.

MacKenzie, D.I., Nichols, J.D., Hines, J.E., Knutson, M.G., Franklin, A.B., 2003. Estimating site occupancy, colonization, and local extinction when a species is detected imperfectly Ecology 84, 2200-2207.

Matson, P.A., Parton, W.J., Power, A., Swift, M., 1997. Agricultural intensification and ecosystem properties. Science 277, 504-509.

McCarthy, M., Masters, P., 2005. Profiting from prior information in Bayesian analyses of ecological data. J. Appl. Ecol. 42, 1012-1019.

McLeman, R.A., Dupre, J., Ford, L.B., Ford, J., Gajewski, K., Marchildon, G., 2014. What we learned from the dust bowl: lessons in science, policy, and adaptation. Popul. Environ. $35,417-440$.

Naugle, D.E., Johnson, R.R., Estey, M.E., Higgins, K.F., 2001. A landscape approach to conserving wetland bird habitat in the prairie pothole region of eastern South Dakota. Wetlands 21, 1-17.

North America Bird Conservation Initiative, 2016. The State of North America's Birds 2016. Environment and Climate Change, p. 8 (Ottawa, Canada).

Noss, R.F., 1990. Indicators for monitoring biodiversity: a hierarchical approach. Conserv Biol. 4, 355-364

O'Connor, R., Dunn, E., Johnson, D., Jones, S., Petit, D., Pollock, K., Smith, C., Trapp, J. Welling, E., 2000. A programmatic review of the North American Breeding Bird Survey. Patuxent Wildlife Research Center, Laurel, Maryland.

Omernik, J.M., 1995. Level III Ecoregions of the Continental United States. Corvallis Environmental Research Laboratory, US Environmental Protection Agency.

Ostlie, W., Haferman, J., 1999. Ecoregional conservation in the Great Plains. Proceedings of the North American Prairie Conference, pp. 136-148.

Pardieck, K., Ziolkowski Jr., D., Hudson, M., 2014. North American Breeding Bird Survey Dataset 1966-2013, Version 2013.0. US Geological Survey, Patuxent Wildlife Research Center (www.pwrc.usgs.gov/BBS/RawData).

Parody, J.M., Cuthbert, F.J., Decker, E.H., 2001. The effect of 50 years of landscape change on species richness and community composition. Glob. Ecol. Biogeogr. 10, 305-313.

Phalan, B., Onial, M., Balmford, A., Green, R.E., 2011. Reconciling food production and biodiversity conservation: land sharing and land sparing compared. Science 333, 1289-1291.

PRISM Climate Group, 2004. http://prism.oregonstate.edu. Oregon State University.

R Development Core Team, 2015. R: A language and environment for statistical computing. R Foundation Statistical Computing, Vienna, Austria (Vienna, Austria).

Radford, J.Q., Bennett, A.F., 2007. The relative importance of landscape properties for woodland birds in agricultural environments. J. Appl. Ecol. 44, 737-747.

Ratajczak, Z., Briggs, J.M., Goodin, D.G., Luo, L., Mohler, R.L., Nippert, J.B., Obermeyer, B. 2016. Assessing the potential for transitions from tallgrass prairie to woodlands: are we operating beyond critical fire thresholds? Rangel. Ecol. Manag.

Raz-Yaseef, N., Billesbach, D.P., Fischer, M.L., Biraud, S.C., Gunter, S.A., Bradford, J.A., Torn, M.S., 2015. Vulnerability of crops and native grasses to summer drying in the U.S. Southern Great Plains. Agric. Ecosyst. Environ. 213, 209-218.

Reidy, J.L., Thompson III, F.R., Amundson, C., O'Donnell, L., 2016. Landscape and local effects on occupancy and densities of an endangered wood-warbler in an urbanizing landscape. Landsc. Ecol. 31, 365-382.

Reitsma, K.D., Clay, D.E., Clay, S.A., Dunn, B.H., Reese, C., 2016. Does the US cropland data layer provide an accurate benchmark for land-use change estimates? Agron. J. 108, 266-272.
Rosenstock, S.S., Charles Van Riper, I., 2001. Breeding bird responses to juniper woodland expansion. J. Range Manag. 226-232.

Rota, C.T., Fletcher Jr., R.J., Dorazio, R.M., Betts, M.G., 2009. Occupancy estimation and the closure assumption. J. Appl. Ecol. 46, 1173-1181.

Royle, J.A., Chandler, R.B., Yackulic, C., Nichols, J.D., 2012. Likelihood analysis of species occurrence probability from presence-only data for modelling species distributions. Methods Ecol. Evol. 3, 545-554.

Samson, F., Knopf, F., 1994. Prairie conservation in North America. Bioscience 44, 418-421.

Samson, F.B., Knopf, F.L., Ostlie, W.R., 2004. Great Plains ecosystems: past, present, and future. Wildl. Soc. Bull. 32, 6-15.

Sauer, J.R., Hines, J.E., Fallon, J.E., Pardieck, K.L., Ziolkowski Jr., D.J., Link, W.A., 2014. The North American Breeding Bird Survey, Results and Analysis 1966-2013. Version 01.30.2015, USGS Patuxent Wildlife Research Center, Laurel, MD.

Schulte, L.A., MacDonald, A.L., Niemi, J.B., Helmers, M.J., 2016. Prairie strips as a mechanism to promote land sharing by birds in industrial agricultural landscapes. Agric. Ecosyst. Environ. 220, 55-63.

Searchinger, T., Heimlich, R., Houghton, R.A., Dong, F., Elobeid, A., Fabiosa, J., Tokgoz, S., Hayes, D., Yu, T.-H., 2008. Use of US croplands for biofuels increases greenhouse gases through emissions from land-use change. Science 319, 1238-1240.

Serran, J., Creed, I., 2016. New mapping techniques to estimate the preferential loss of small wetlands on prairie landscapes. Hydrol. Process. 30, 396-409.

Sparks, T.H., Parish, T., Hinsley, S.A., 1996. Breeding birds in field boundaries in an agricultural landscape. Agric. Ecosyst. Environ. 60, 1-8.

Sturtz, S., Ligges, U., Gelman, A., 2005. R2WinBUGS: a package for running WinBUGS from R. J. Stat. Softw. 12, 1-16.

The Cornell Lab of Ornithology, 2016. All About Birds.

Tilman, D., 1994. Competition and biodiversity in spatially structured habitats. Ecology 75 , $2-16$.

Twidwell, D., Rogers, W.E., Fuhlendorf, S.D., Wonkka, C.L., Engle, D.M., Weir, J.R., Kreuter, U.P., Taylor, C.A., 2013. The rising Great Plains fire campaign: citizens' response to woody plant encroachment. Front. Ecol. Environ. 11, 64-71.

Twidwell, D., West, A.S., Hiatt, W.B., Ramirez, A.L., Taylor Winter, J., Engle, D.M., Fuhlendorf, S.D., Carlson, J.D., 2015. Plant invasions or fire policy: which has altered fire behavior more in tallgrass prairie? Ecosystems 19, 356-368.

U.S. Environmental Protection Agency, 2010. NA CEC Eco Level 3. U.S. EPA Office of Research \& Development (ORD) - National Health and Environmental Effects Research Laboratory (NHEERL), Corvallis, OR.

USDA National Agricultural Statistics Service Cropland Data Layer, 2016a. Published Crop-specific Data Layer.

Vickery, P.D., Herkert, J.R., Knopf, F.L., Ruth, J., Keller, C.E., 1995. Grassland birds: an overview of threats and recommended management strategies. In Strategies for Bird Conservation: The Partners in Flight Planning Process. Proceedings of the Third Partners in Flight Workshop, pp. 74-77.

Vickery, J., Tallowin, J., Feber, R., Asteraki, E., Atkinson, P., Fuller, R., Brown, V., 2001. The management of lowland neutral grasslands in Britain: effects of agricultural practices on birds and their food resources. J. Appl. Ecol. 38, 647-664.

Watson, J.E.M., Whittaker, R.J., Dawson, T.P., 2004. Habitat structure and proximity to forest edge affect the abundance and distribution of forest-dependent birds in tropical coastal forests of southeastern Madagascar. Biol. Conserv. 120, 311-327.

Weir, J.R., Scasta, J.D., 2014. Ignition and fire behaviour of Juniperus virginiana in response to live fuel moisture and fire temperature in the southern Great Plains. Int. J. Wildland Fire 23, 839-844

Wessman, C.A., Archer, S., Johnson, L.C., Asner, G.P., 2012. Woodland expansion in US grasslands. Land Change Science. Springer, pp. 185-208.

Whittingham, M.J., Evans, K.L., 2004. The effects of habitat structure on predation risk of birds in agricultural landscapes. Ibis 146, 210-220.

Wickham, H., 2009. Ggplot2: Elegant Graphics for Data Analysis. Springer.

Wilson, J.D., Morris, A.J., Arroyo, B.E., Clark, S.C., Bradbury, R.B., 1999. A review of the abundance and diversity of invertebrate and plant foods of granivorous birds in northern Europe in relation to agricultural change. Agric. Ecosyst. Environ. 75, 13-30.

Wright, C.K., Wimberly, M.C., 2013. Recent land use change in the Western Corn Belt threatens grasslands and wetlands. Proc. Natl. Acad. Sci. 110, 4134-4139.

WWF, 2016. Plowprint report. Facts and Figures.

Zou, C.B., Qiao, L., Wilcox, B.P., 2015. Woodland expansion in central Oklahoma will significantly reduce streamflows-a modeling analysis. Ecohydrology. 